\title{
The Joseph Lemaire Sanatorium in Belgium: A Forgotten Modern Masterpiece
}

\author{
By Rossella Putzolu*
}

\begin{abstract}
The Joseph Lemaire Sanatorium, completed in 1937 in Belgium, is one of the masterpieces of sanatorium typology, which spread from the end of the 18th Century to the 1930s, when they were characterized by the principles of the International Style. Lemaire Sanatorium was designed by Maxime Brunfaut with a main hospital building, a wing for general services and superposed leisure rooms. The Modernity of this work is traceable certainly in the composition and in the constructive technology of the complex, with a capable use of modern materials. Brunfaut's formal language is strongly modern also thanks to the distinction amongst functions, services, spaces dedicated to clinic duties, to the leisure and to administrative functions. Great importance is also given to the technical features, either under the principles of Hygienism either to the Functionalism of the Modern Movement. Unfortunately at the end of the 1980s it was dismissed, so the building was exposed to degradation and vandalism that transformed this site into a devastated ruin with serious problems affecting fixtures, inner spaces and loaded parts. Despite its inscription as a historical and architectural monument in 1993, only in 2011 the Flemish Minister of Cultural Heritage started its restoration, which is still far from being concluded.
\end{abstract}

\section{Introduction}

Tuberculosis has always been a social plague in the world, but only two centuries ago they started to treat it as a proper disease with sanitary approaches, specific clinics and modern medical studies. Since the $19^{\text {th }}$ Century there was a proliferation of sanatoriums, intended to treat TBC patients, both in Europe and the United States. In those buildings, few and exclusive initially, people lived apart from the rest of the world and underwent to physical and clinical therapies, i.e. heliotherapy, working therapy, diet and so on. ${ }^{1}$

In 1882 Robert Koch discovered the TBC bacillus, ${ }^{2}$ but almost sixty years had to pass before a proper treatment, the streptomycin, was discovered by Selman Waksman in 1940. Until then, there were simple and palliative therapies, based on curative properties of dry air and sun that implied to sanatorium buildings to be built in alpine locations, possibly isolated and surrounded by nature. ${ }^{3}$

\footnotetext{
${ }^{*}$ PhD Student, University of Cagliari, Cagliari.

1. Frank Ryan, Tuberculosis: the greatest story never told (Bromsgrove: Swift Ed, 1992).

2. Mycobacterium tuberculosis, aka Koch Bacillus, belongs to Mycobacteriaceae family. [A. N.]

3. Margareth Campbell, Architecture of hope: hope for a cure. Tuberculosis, a design response, graduation thesis by Phil, M (Edinburgh: Heriot-Watt University, 1999); Davide Del Curto, Il Sanatorio Alpino. Architetture per la cura della tubercolosi dall'Europa alla
} 
The causes of the spreading of TBC amongst people from different social backgrounds was initially connected to the fast growth of urban towns, during the First Industrial Revolution: people from farmlands came to towns to live in workers' overcrowded boroughs, suffering from malnutrition and insalubrity. The situation was so critic till the point that in the mid of 19th Century one four deaths was caused by phthisis. ${ }^{4}$

Despite the interest of socialist organizations, like the Garden Cities Movement in the UK or the Lebensreform ${ }^{5}$ in Germany, to grant to workers more healthful living standards and salubrious homes, the plague did not stop from spreading and the national economic system was affected too.

Only in the late $19^{\text {th }}$ Century a social phenomenon, called sanatorium movement, that aimed to promote the jour medical as the only possible treatment for TBC, started: several weeks, months or years of heliotherapy, diet and manual works to be practiced into specific buildings, the sanatoriums, built by philanthropists and phthisiologists. One of the first and most famous was the Hermann Brehmer's Görbersdorf Sanatorium in Davos that promoted the Switzerland locations as the best curative regions in Europe. ${ }^{6}$

\section{Sanatorium Architecture}

The architectural response to improve living spaces, making them more luminous and ventilated, was promoted by new formal and constructive approaches at the end of the $19^{\text {th }}$ Century: new building systems, such as steel and concrete frames, allowed architects to be free from bearing masonry thanks to pillars and beams (sponsored by Hennebique Company since 1880s) and to formulate new theories about buildings, openings, empty - full relationships, formal compositions etc. Through the progress of modern construction and architecture theories a new order of things replaced the old one and buildings were changing: far from Neoclassicism and Romanticism, architects refused Eclecticism to clean and light forms, banding decorations and unnecessary features. ${ }^{7}$

Valtellina [The Alpine Sanatorium. Architectures for the cure of tuberculosis from Europe to Valtellina] (Rome: Aracne, 2010).

4. O. R. McCarthy, "The key to the sanatoria," in Journal of the Royal Society of Medicine (London : Royal Society Of Medicine, 2001), 413-417.

5. The Lebensreform (Reform of Life) movement was a social movement that emphasized physical fitness and natural health. Proponents of Lebensreform valued connecting with nature and all sorts of political and lifestyle components that come with it: paganism, feminism, psychoanalysis, pacifism, yoga, and Eastern religions like Buddhism and Hinduism. The Lebensreform movement created their own schools, their own clinics, and intentional communities [A. N.].

6. Linda Bryder, Below the magic mountain: a social history of tuberculosis in twentiethcentury Britain (Oxford [Oxfordshire]: Clarendon Press, 1988).

7. Edward Ford, The Details of Modern Architecture (Cambridge: MIT Press, 1996); Kenneth Frampton, Storia dell'Architettura Moderna [History of Modern Architecture] (Bologna: Zanichelli, 1986). 
Proto - modern architecture, recognizable in buildings like Josef Hoffmann's Purkersdorf Sanatorium in Wien - answered to the need of light, sun, ventilation and accessibility of sanatoriums designing elements that would have soon become peculiar of the later Modern language: terraces, garden roofs, balconies and closable verandas were traduced and performed by Modern Movement into flat roofs, pedestrian roofs, ribbon windows, bow windows, free plants and so on. ${ }^{8}$

If we think of sanatoriums and clinics, we refer to the 1930s projects by Alvar Aalto, Duiker and Bijvoet and H. G. Pingusson (see Figure 1), who designed their sanatoriums applying excellently the principles of the Modern Movement, conceiving architectural aspects, furnishings, hues and technologies to improve patients' health and lives.

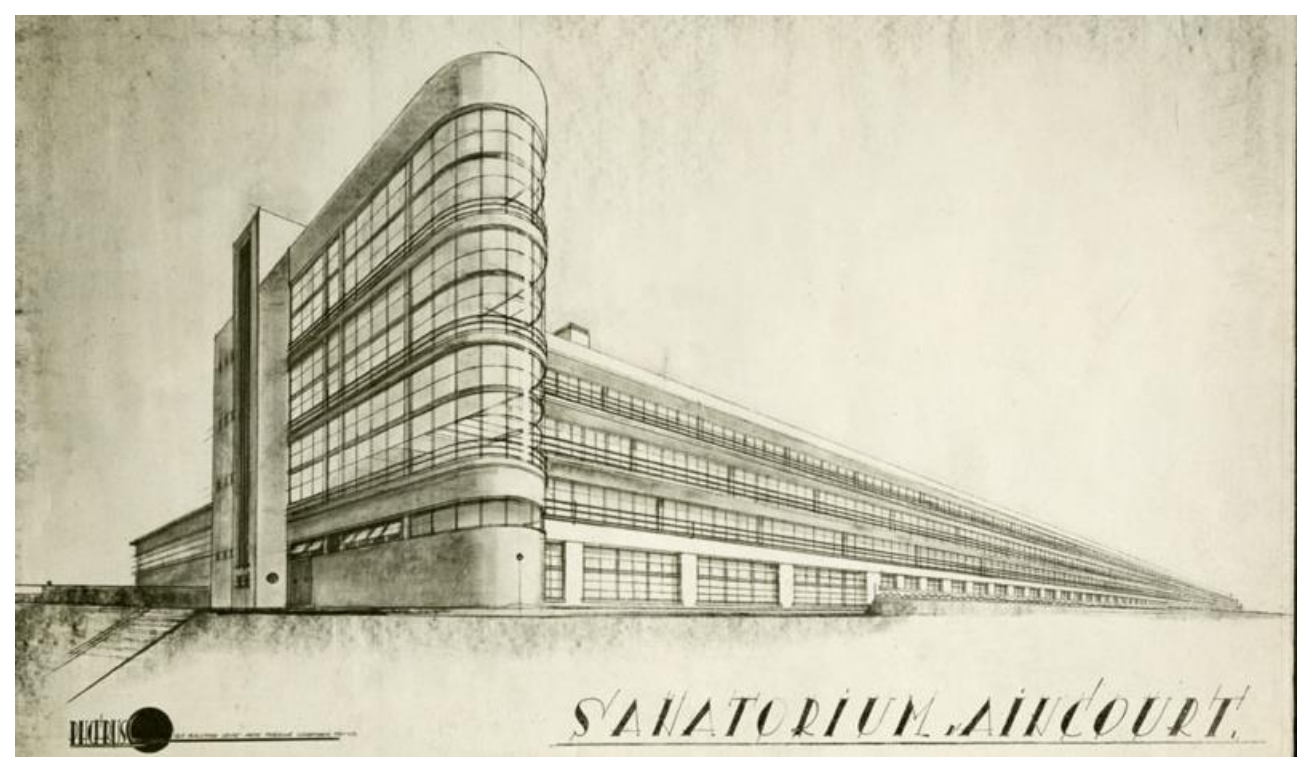

Figure 1. The Aincourt Sanatorium by H. G. Pingusson

Source: Architecture d'Aujourd'hui, 31932.

Sanatoriums in Modern Architecture

\section{Zonnestraal Sanatorium}

One of the most representative building of sanatorium architecture is certainly the Duiker and Bijvoet's Zonnestraal Sanatorium, in Holland (see Figure 2).

The intent here is combined with a holistic approach ${ }^{9}$ in confront of the patients' lifestyle: starting from the name of the site - Zonnestraal means sunbeam - to the search of natural illumination and contact with nature, to the

8. Eduard Franz Sekler, Josef Hoffmann. Das Architektonische Werk [The Architectural Work] (Saltzburg: Residenz Verlag, 1982); Eduard Franz Sekler, Josef Hoffmann 1870-1956 (Milan: Electa, 1991).

9. Maristella Casciato and Wessel De Jonge, Johannes Duiker e il costruire funzionalista [Johannes Duiker and the functionalist building] (Milan: Mondadori, 1989). 
disposition of the pavilions in the site, there is a constant recall of the positive influence of environment, manual works, sun and air on both physical and psychological healing. ${ }^{10}$

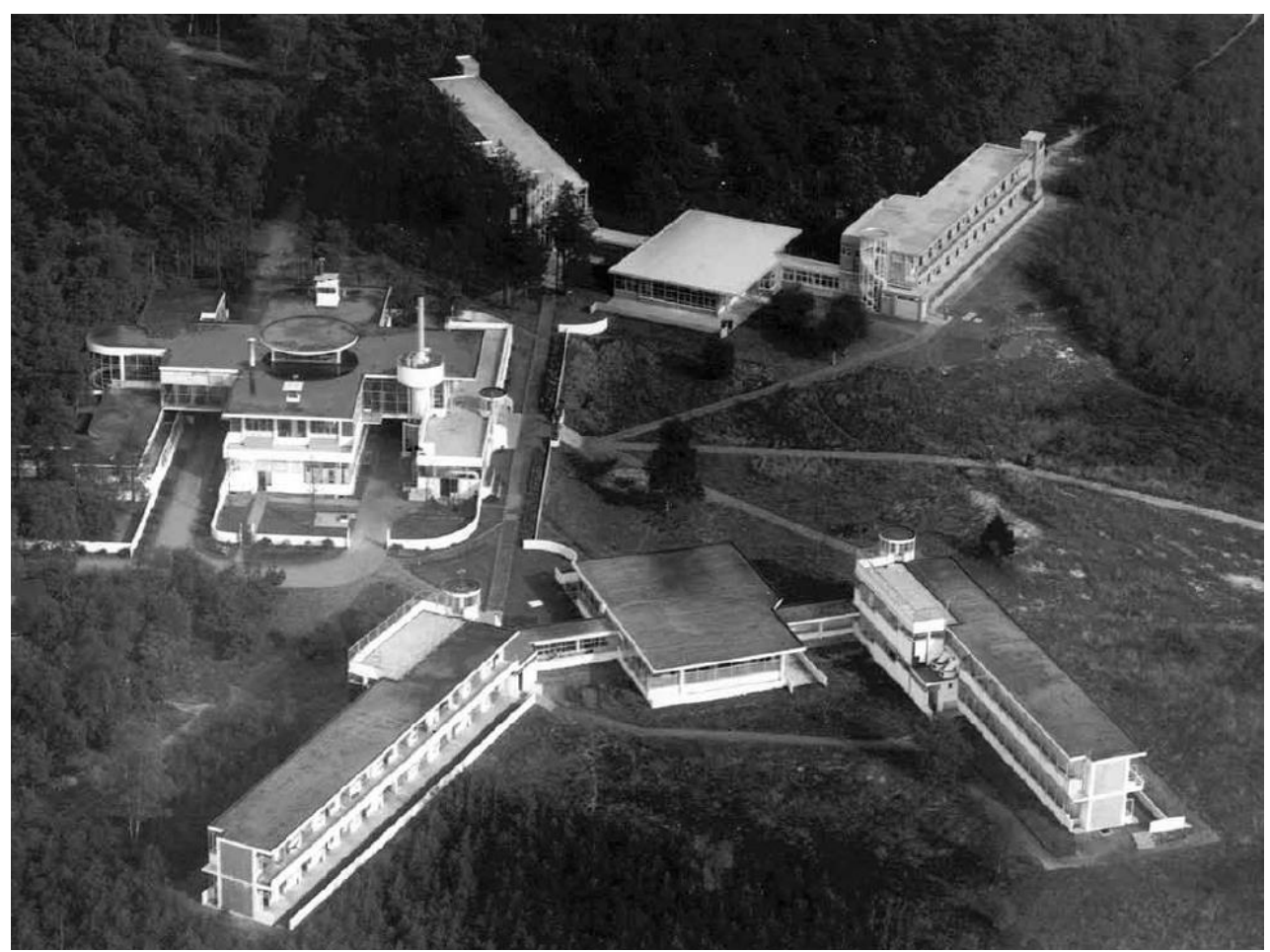

Figure 2. Zonnestraal Sanatorium in 1931

Source: World Monuments Found, www.wmf.org.

It was commissioned in 1919 by the Dutch Syndicate of Diamond Cutters that aimed to grant to workers affected by TBC a proper treatment facility. The construction started in 1927 and it was finished in 1931.

In the final project of 1925 architects chose a main building on the north and four pavilions linked by a web of diagonal pathways. Of these four, only two were realized.

The main building counts several asymmetrical volumes that hosted services and common functions: offices on the north, kitchens in the middle, laundry and services on the south. On the main floor, accessible from a marvelous helicoidal staircase put inside a glazed cylinder, there are the main hall and the terrace that looks to the detached pavilions and the gardens. The view from this point shows certain symmetry in their disposition, but the

10. Vittorio Prina, Jan Duiker: Sanatorio Zonnestraal a Hilversum [Jan Duiker: Zonnestraal Sanatorium in Hilversum] (Florence: Alinea, 2006); Paul Meurs and MarieThérèse van Thoor, Sanatorium Zonnestraal: History and Restoration of a Modern Monument (Rotterdam: nai010 Publishers, 2011); Gabriele Milelli, Zonnestraal. Il sanatorio di Hilversum [Zonnestraal. The Hilversum Sanatorium] (Bari: Dedalo Libri, 1978); Giovanni Fanelli, Architettura Moderna in Olanda [Modern Architecture in Holland] (Florence: Marchi e Bertolli, 1968). 
perception is only ephemeral: following the paths there is a strong dynamic tension that magnifies their diagonal position.

Bearing structure is really impressive and peculiar: dimensions and thickness are reduced to the minimum, opposite to the maximum extension of distances amongst the parts: main spans are 9 meters, floors are just $8 \mathrm{~cm}$ thick and cantilevers are $1.50 \mathrm{~m}$ long.

Unfortunately, to reduce costs, builder used poor resistant materials, especially in windows frames: being in non - galvanized steel they rapidly degraded despite the fact that they were supposed to last at least 30 years and to be maintained by patients. Architects opted for curtain walls to grant an amount of light and ventilation, but the 1928 project was only a prototype. The main structure of 1928 was built with a prototype without expansion joints amongst frames and it caused a huge quantity of problems in controlling dimensions during the restoration project. Moreover, the frames were $25 \mathrm{~mm}$ thick and therefore the original glass panels were thin but too wide -1.50 meters - and instable. This mistake was corrected in a second pavilion, where steel frames are $40 \mathrm{~mm}$ thick and panels are smaller.

The complex was dismissed and transformed since the 1950s: some pavilions were sensibly modified with alteration of the former chromatic, curtain walls - replaced by aluminum double glazed windows - and inner disposition.

In 1995 the architects Jan Henket and Wessel de Jonge, founders of Docomomo International, started a restoration project to recover the site as part of a general plan of conversion of the former sanatorium into a clinic. ${ }^{11}$

One of the hardest parts ${ }^{12}$ was the recovering of the curtain walls: due to the thickness of the frames, they replaced them with thicker ones similar to those of the second pavilion (1931) and they inserted expansion joints. The glazed panels, that had to grant the same transparency as the former ones, were imported from abroad and they were made of floated glass combined with a mono glass, placed in the common parts of the building; due the high costs, mono glasses were left for minor parts, as corridors and staircases.

The concrete parts, really damaged and degraded due decades of abandon, were restored and along with the original lightness and transparency of glazed cases, they made the building looking as in the past (see Figure 3). The restoration program opted for a new function, similar to the former one, as it has become a nursing home.

11. Wessel De Jonge, "Zonnestraal: Restoration of a transitory architecture. Concept, planning and realization in the context of its authenticity," paper presented at the $7^{\text {th }}$ International DOCOMOMO Technology Seminar, Viipuri Library, Vyborg, Russia, September 18-19, 2003.

12. Paul Meurs and Marie-Thérèse van Thoor, Sanatorium Zonnestraal: History and Restoration of a Modern Monument (Rotterdam: nai010 Publishers, 2011). 


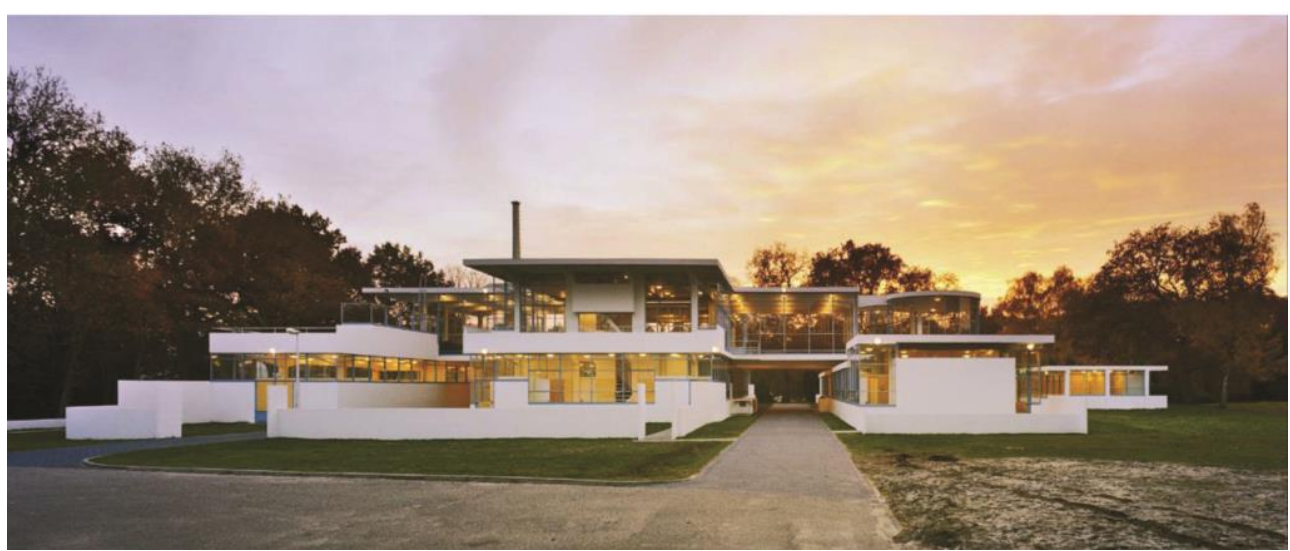

Figure 3. Zonnestraal After the Restoration and the Reopening

Source: World Monuments Found, www.wmf.org.

\section{Paimio Sanatorium}

In architectural literature the most important reference to sanatorium buildings is the Finnish Paimio Sanatorium by Alvar Aalto. ${ }^{13}$ It can be considered as a modern masterpiece of clinic architecture and Functionalism: it was built from 1930 to 1933 in a pinewood location, isolated into a sandy and dry environment, which was ideal for TBC treatments.

The Sanatorium counts a main building, the head physician's house today transformed into a kindergarten - staff's houses, a mortuary, boilers' room and nurses' houses.

Inside the main building there is a separation amongst departments that are: patients' pavilions, common facilities and leisure rooms, clinical areas, kitchens and services wards. Each department is independent and oriented in order to get the most favourable exposition and those which have similar necessities are placed together.

Patients are hosted in a specific pavilion: a seven storey building, with a main façade that is the most representative and distinctive feature of the complex, thanks to its narrow and high dimensions. Ribbon windows run on the northwest side revealing the corridors on the rear. The disposition is studied in order to let sunlight flood in patients' rooms as much as possible, while the hottest light during afternoon and evening is deeply reduced.

In the patient's wings there are the balconies for and a roof terrace (see Figure 4) on the top of the wing, where patients could stay together in the lounges facing the woods.

13. Roberto Bray, Alvar Aalto. Spazi e processo architettonico [Alvar Aalto. Spaces and architectural process] (Bari: Dedalo Libri, 1984); Karl Fleig (ed.), Alvar Aalto (Bologna: Zanichelli, 1978); Peter Reed (ed.), Alvar Aalto (Milan: Electa, 1999); Arnold Whittick, Architettura europea del XX Secolo [European Architecture in the 20 ${ }^{\text {th }}$ Century] (London: Crosby Lockwood \& Son, 1950). 


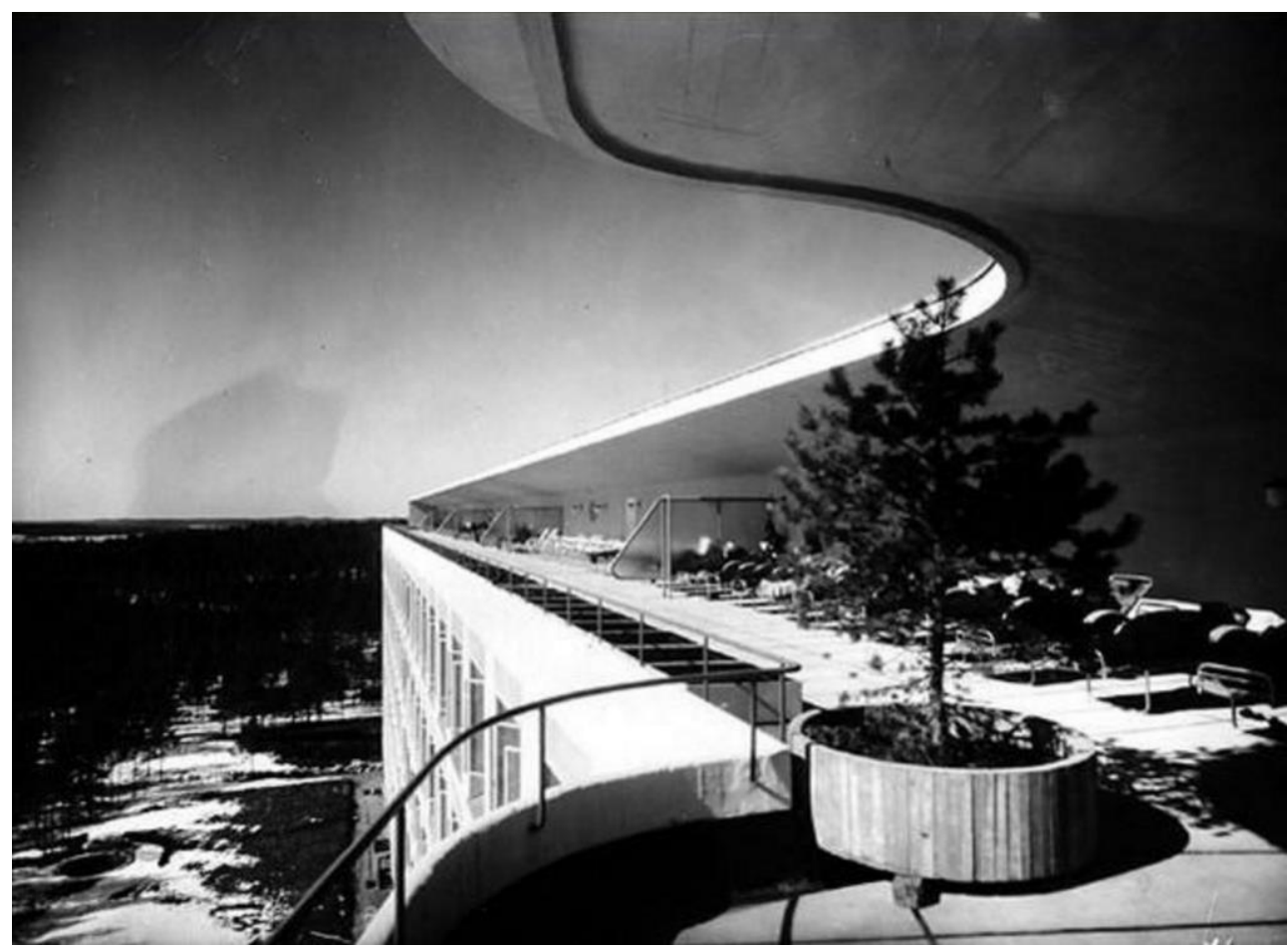

Figure 4. The Terrace on the Roof

Source: www.studyblue.com.

Patients' rooms were designed to grant them the calmest atmosphere when lying on beds: lighting, ventilation, acoustics and efficiency of waste management were designed to be as quiet and comfortable as possible: silent basins were inclined to avoid water to flood noisily; windows had an opening system that granted silent movements of the gears; technical devices are placed inside a pipeline outside the rooms. Wardrobes were suspended on walls in order to allow pavements to be completely cleaned without exceptions and bed lights were fixed on the headboards so night tables were entirely at the patients' disposal. ${ }^{14}$

Glazed panels feature common parts of the main building: the suspended café looks down into the dining room through a curtain wall and they both look outside through the pavement to the floor windows all along the façade. The main staircase offers itself a pleasant view to the forest, being widely glazed, and it shows an uninterrupted balustrade that runs continuously for all the stairs.

Paimio was converted to a general hospital in 1971, with several modifications but the original partitions remained as they were. Aalto's atelier was in charge for the conversion works in 1991 along with the National Council for Antiques: exteriors, original interiors, furnishing and pipelines were put under protection and several rooms where left as a memorial of

14. Gabriella D’Amato, Storia del Design [History of Design] (Milan: Bruno Mondadori, 2005); Timo Keinänen et al., Alvar Aalto e gli oggetti [Alvar Aalto and the objects] (Milan: Electa, 2004). 
Aalto's project (see Figure 5). In 2005 the Council for Antiquities presented Paimio to the UNESCO World Heritage Committee to be enlisted in the World Heritage List.

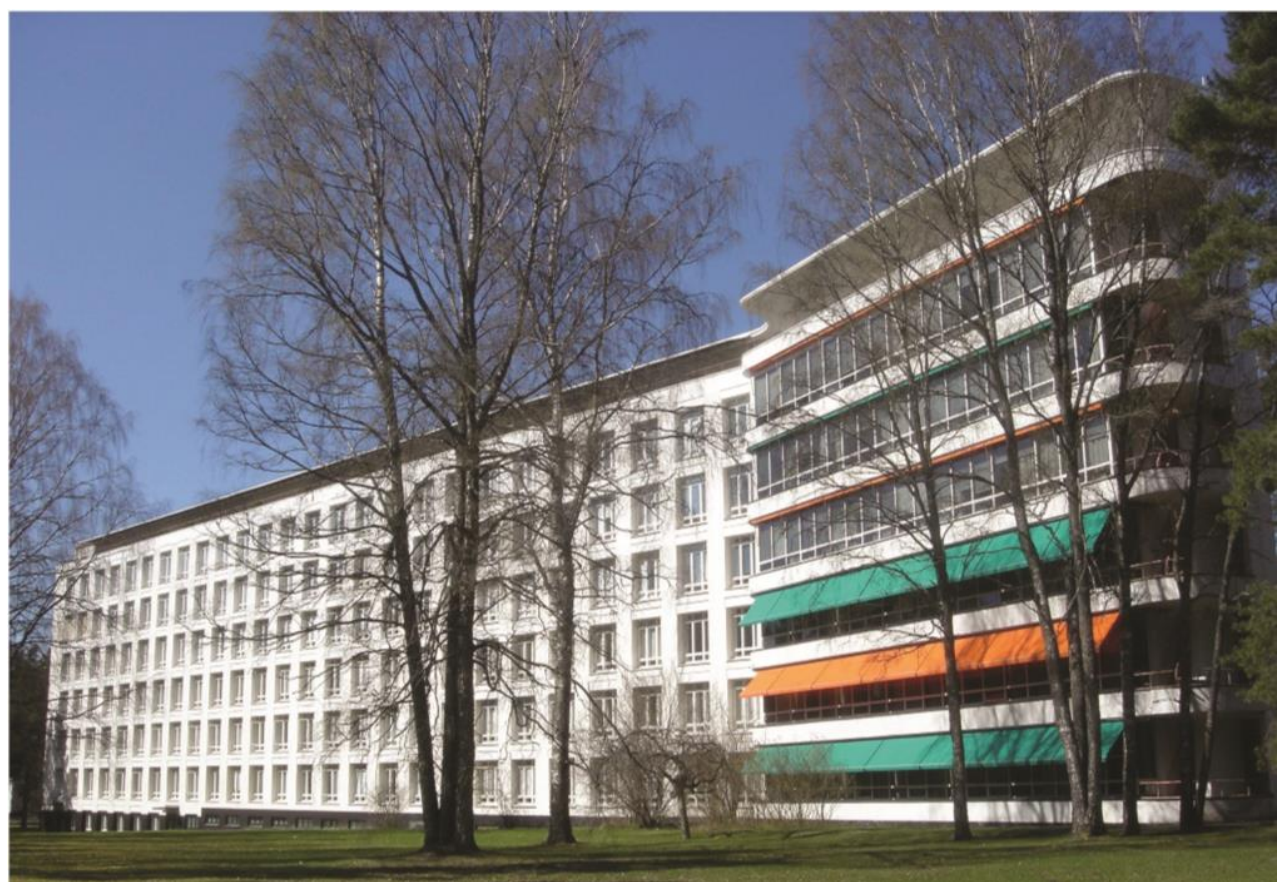

Figure 5. Paimio Sanatorium at Present Days

Source: www.skyscrapercity.com.

\section{Joseph Lemaire Sanatorium}

On $30^{\text {th }}$ September 1937 was inaugurated in Tombeek (Overijse, Flemish Brabant) in Belgium the Joseph M. Lemaire Sanatorium, under the attention of international critics, focused most of all on functionalist and building features responding to the International Style principles. These were indeed yet appreciated either in same - purposed buildings, either in residential ones, such as in Le Corbusier's and in Bauhaus' buildings.

The Prévoyance Sociale, the assurance company owner of funds and of the entire project, had bought a residential zone on south from Bruxelles (see Figure 6). The functional program and projects were assigned to architect Maxime Brunfaut, along with his father, with the collaboration of Joseph Lemaire, manager of the Prévoyance Sociale.

The Sanatorium was completed in the record time of 13 months $(10 / 08 / 1936-21 / 09 / 1937)$ thanks to the contractor N. V. Bémat from Liege and the total cost amounted to more than 14. 000. $000 \mathrm{fr}^{15}$ This building, clearly modern both in formal and constructive features, was used initially as a sanatorium for $\mathrm{TBC}-$ ill patients and then as a hospital.

15. Greta Paesmans, "Het Sanatorium te Overijse (Tombeek) [The Sanatorium in Overijse (Tombeek),]" in M\&L Monumenten en Landschappen 6 (Brugge: Die Kure, 1987), 28. 


\section{The Site}

On July 15, 1934 La Prévoyance Sociale bought an area of 33 ha 49 a 40 ca, located on a $85 \mathrm{~m}$ high table-land where geographical conditions were optimal for a sanatorium. The wide avenue leads to the sanatorium, while in the foothills we find several separate service buildings: the concierge's house, house of a doctor (partly destroyed by a fire), a mortuary, the residence of the staff, laundry and technical buildings. ${ }^{16}$

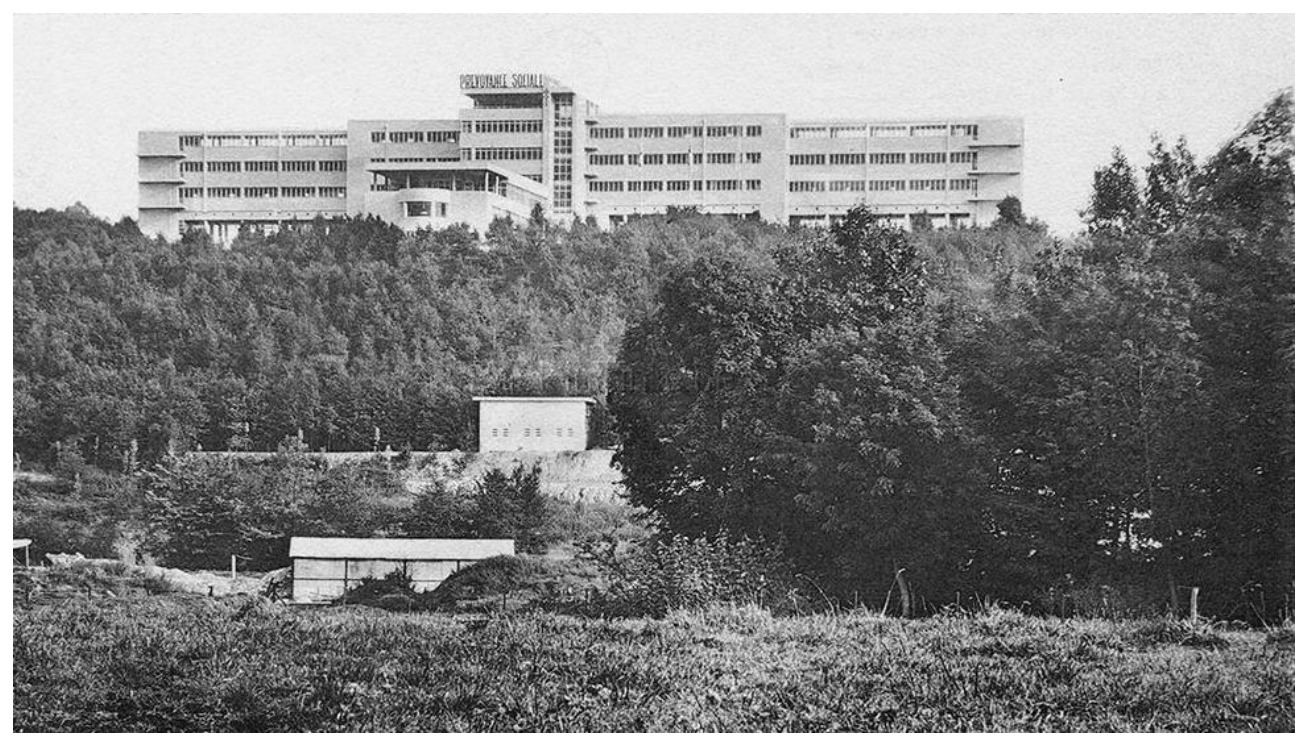

Figure 6. A View from the Tombeek Road

Source: www.delcampe.net.

\section{The Building}

The Sanatorium, designed to host 150 male patients, is composed by (see Figures 7-8):

- a main building reserved to the hospital, 120 meters long, whose main façade is south - oriented;

- a two - storey perpendicular wing, directed to northwest, containing general services;

- a ball room and a leisure room, that forms a superposed low wing bulging over the ground floor on southeast.

16. L. Novogordsky, "Le sanatorium Joseph Lemaire à Tombeek (Brabant) [The Joseph Lemaire Sanatorium in Tombeek (Brabant),]" in La Technique des Travaux 14 (Bruxelles: La Technique des Travaux, 1938). 


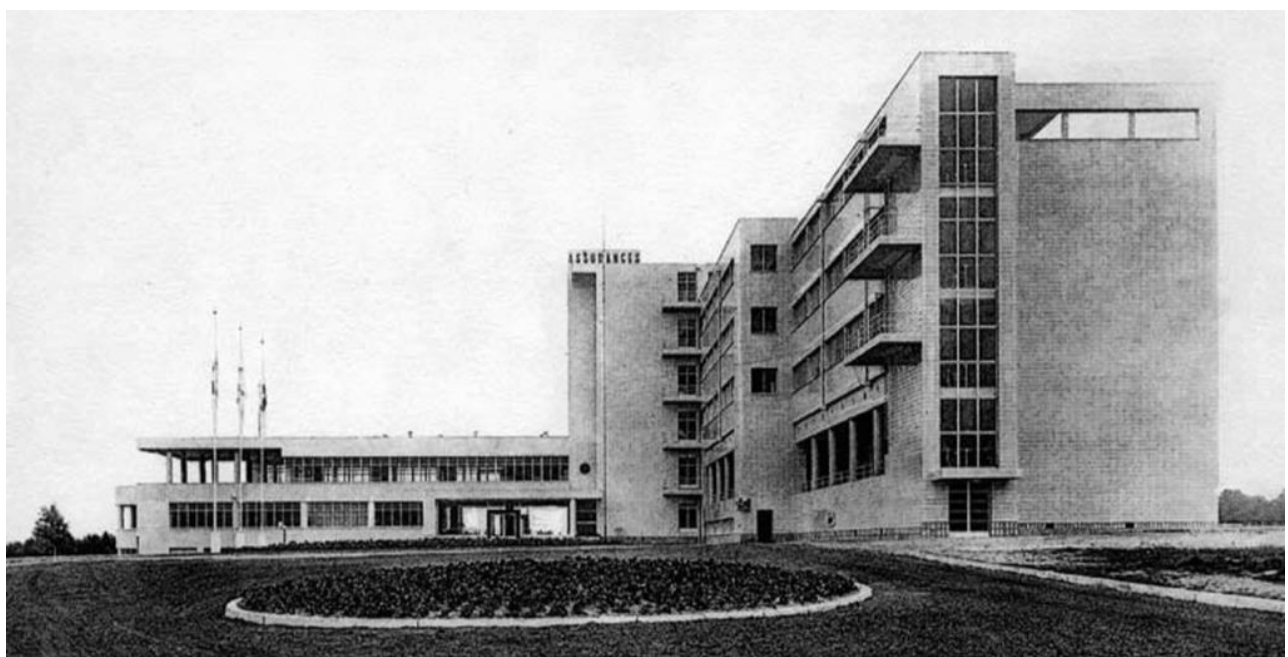

Figure 7. View of the Main Wing

Source: http://bit.ly/2c7d2sg.

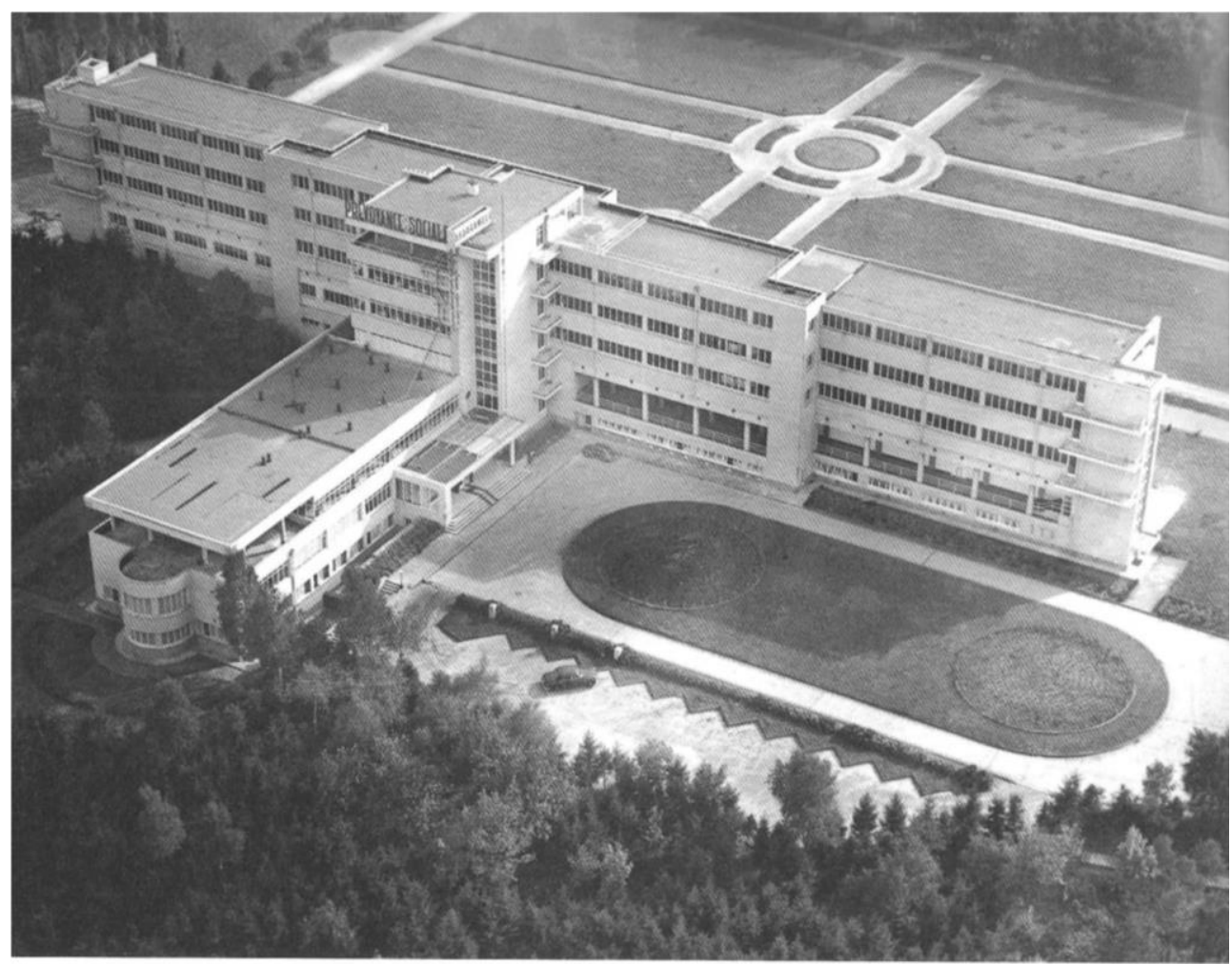

Figure 8. Bird's-eye View of the Northwest Front

Source: www.docomomo.be.

The northwest wing contains on the ground floor the entrance and medical services: control rooms, such as offices, laboratories and radiology; surgery group with surgery rooms, sterilization, disinfection and anesthesia; stomatology, otolaryngology and hydrotherapy. Half of this floor extends for half into the basement of the main building and a large stair leads to the ball room, partly subterranean. 
On the first floor of the northwest wing there are the refectory, the meeting rooms for patients, the corridors and therapeutic galleries. Corridors slope into the play room over the ball room.

On the same floor, kitchens communicates with refectory by an intermediate office; they are linked to the service of preparation of meals (peeling, butchery, fridges etc...), placed on the second underground floor of northwest wing, two an elevator hoist, an elevator and a stair.

Between the ground floor, with medical services, and the second subterranean floor, with rooms annexed to the kitchens and the stores, there is an intermediate floor on the northwest side reserved to nurses: it is composed of 12 rooms, meeting and resting rooms.

Patients' rooms are located onto the three upper floors in the main building, with accommodations from one to three beds. In the patients' wing on the ground floor there are terraces to be used by patients to practice heliotherapy, facing the French gardens.

Medical services comprehend also the dependences for the staff, the guardian's and the gardener's houses, the manager's house, heating station, laundry and watering pumps.

The Sanatorium took obviously in great consideration the importance for patients' health that underwent heliotherapy: the cure open gallery (see Figure 9) was therefore placed in both the south and north façades, extending over to the entire width and depth of the patients wing. The gallery was on two cascading levels, where double rows of lounger could be disposed and supporting column structure was studied to avoid shade zones, offering to each patient a maximum views and sunlight.

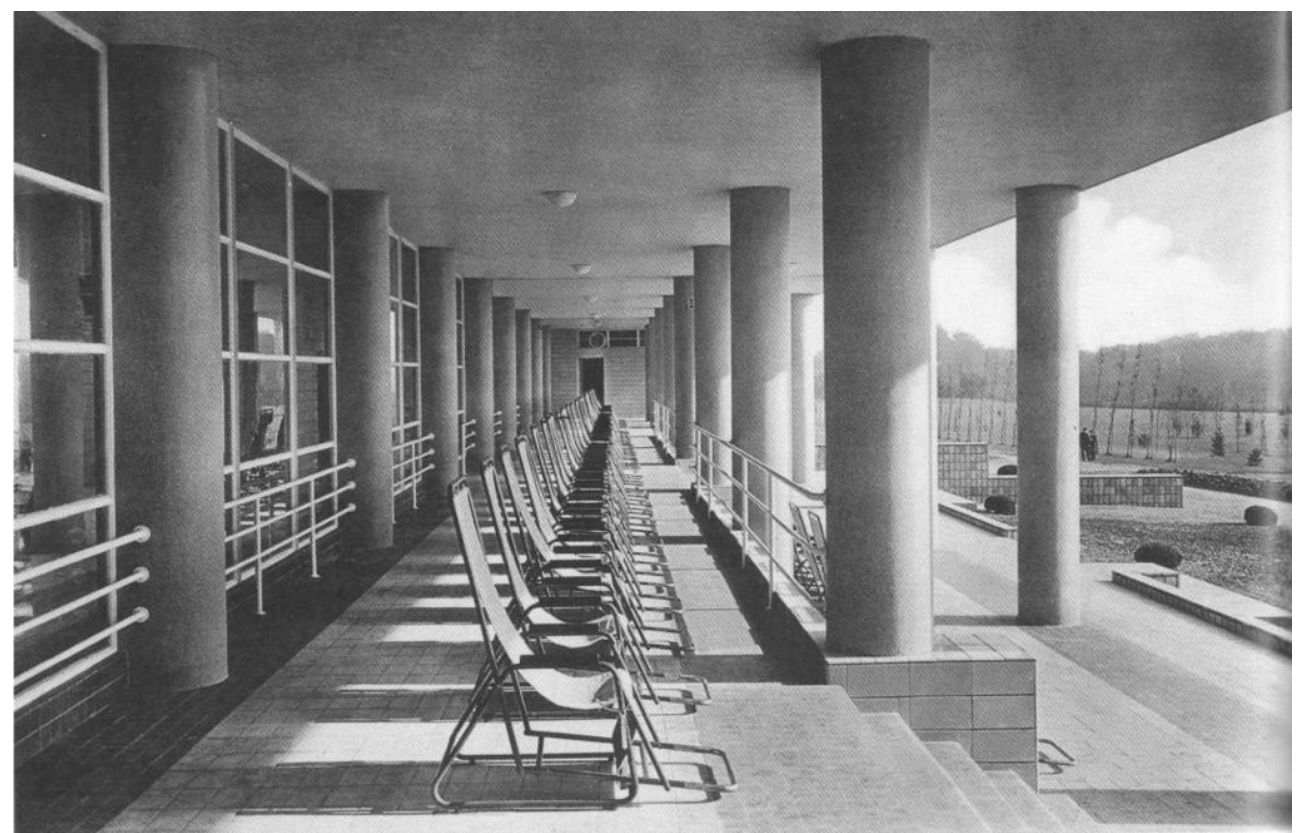

Figure 9. The Cure Gallery in 1938

Source: www.docomomo.be. 
As in the most cases, much attention was paid to the leisure and entertainment aspects for able - bodied patients in the facility, whose minimum staying lasted eight months. Therefore architects designed collective spaces, such as a dining room, lounge, library, card room and an entertainment hall. The latter was developed into a horseshoe - shaped fully glazed pavilion, which extents half underground, intended for film and stage performances. Above this extended volume there is an identical room for billiards and related activities.

This projecting body lengthening in the middle of the garden put itself as an arresting volume in the seemingly limitless façade of the long main structure (see Figure 10).

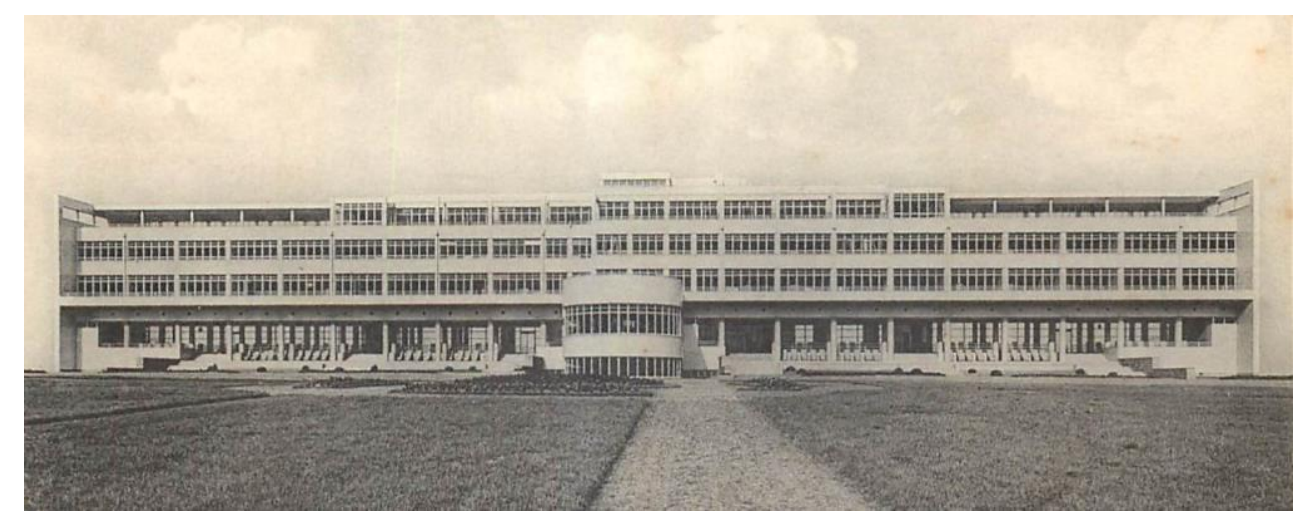

Figure 10. View of the South Front

Source: www.delcampe.net.

On the other side, in the north façade, this stress finds its counterpart in an openwork rotunda, looking like a theater, combined with a covered terrace that overlooks to the Valley Lane.

Construction $^{17}$

The Sanatorium has a regular structural partition made by concrete frames, inscribed into axes obtained by the canvas of pillars and beams: 5.60 meters in parallel to the façades, 4.30 meters in perpendicular direction. The structural composition of pillars and columns is clearly visible everywhere, underlining the geometrical relationship amongst spaces, structure and volumes.

The inner walls and external fillings are doubled and separated from the concrete parts by compressed cork boards, with a view to an optimal thermal and acoustic insulation, while expansion joints are provided along the entire length of the main structure, dividing it into eight independent compartments. Light is provided by broad, horizontal glass windows.

External coverings made of ceramic enameled tiles $18 \times 39 \mathrm{~cm}$, cream shaded, are placed over a layer of concrete mortar, standing on a galvanized

17. Andre Hermant, "Constructions Hospitalières [Hospital Buildings,]" L'Architecture d'aujourd'hui 5 (Boulogne-sur-Seine: L'Architecture d'aujourd'hui, 1938), 72-73. 
framework fixed on fillings by steel hooks. The tiles are provided also with grooves on the backside to grant perfect adherence with their support. It was one of the first applications in our country where a finish with 'wear-resistant' wall tiles was realized on such a large scale.

The flat, linear façade of the service wing creates a strong contrast to the highly sculptural effect of the main wing, which extends and bulges from the latter, accentuating the gradual shifting of volumes and the deep shadows of the horizontal windows. The entrance and projecting balconies and terraces, bordered by clean lines of metal parapets, are a direct result of the medical requirement to absorb as much light and air inside the building.

The first floor of the hospitalization is separated from the ceiling of the therapy sectors by a horizontal pipeline, 1.80 meters high, where canalizations and pipes are placed; moreover this expedient decreases thermal dispersions through the ceiling and worked as a kind attic punctuated by round windows.

All the floorings - with the exception of the black and white marble floor in the hall (see Figure 11), decorated with the Prevoyance Sociale logo (see Figure 12), and the tiled floor in the kitchen and baths - are covered by a 4.5 $\mathrm{mm}$ thick layer of white linoleum as like as the 1.50 meter high panels on the walls, covered by $1.5 \mathrm{~mm}$ thick cinnamon hue linoleum.

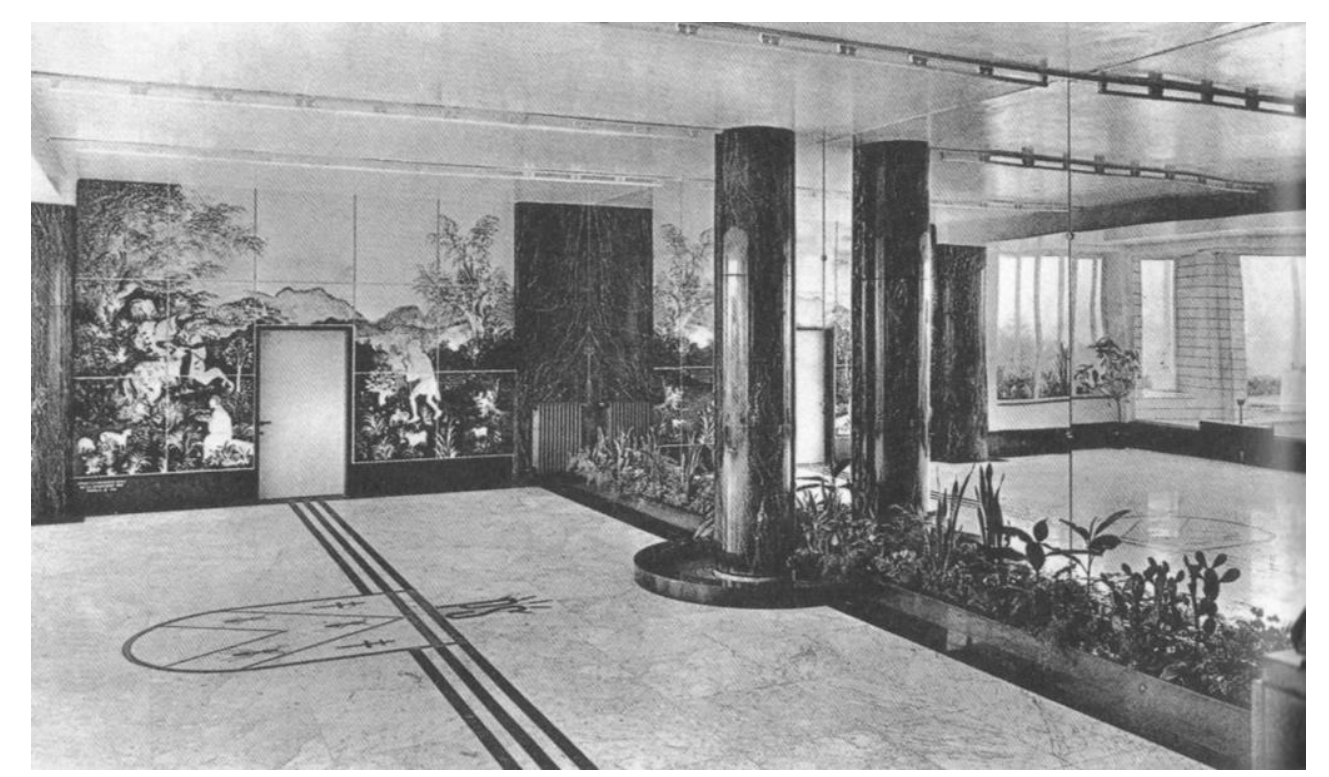

Figure 11. The Entrance Hall

Source: Archive AMSAB-ISG, Gent. 


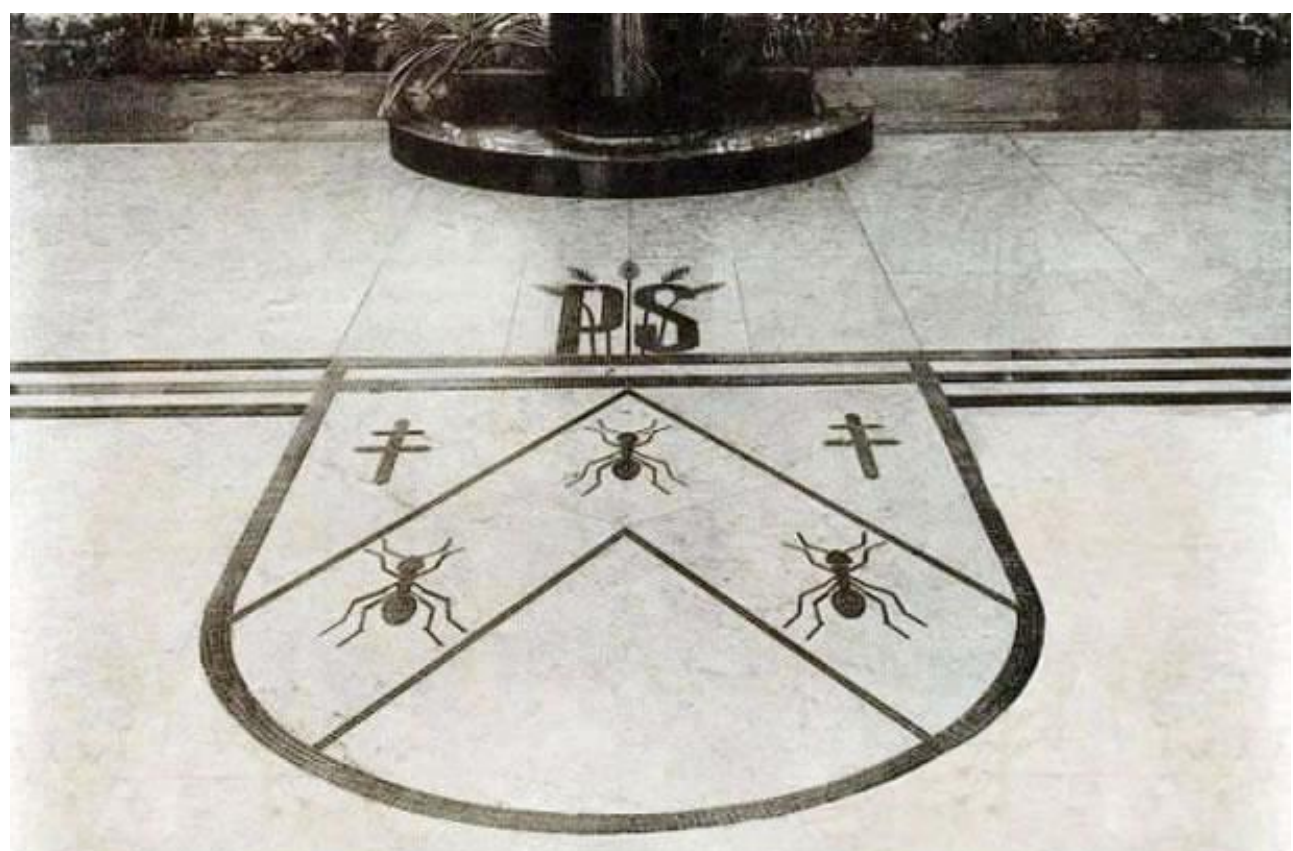

Figure 12. The Prévoyance Sociale Logo with Ants Symbolizing Workforce Source: Archive AMSAB-ISG, Gent.

Heating is provided by vacuum sealed steam, which allows a wide distance between the boiler and the building to serve, a full speed (necessary in a sanatorium) and to supply rapidly and directly certain systems, like kitchens, sterilization rooms and so on. ${ }^{18}$

Brunfaut designed an ingenious stairs system in order to promote either movement therapy for patients, either separation amongst service spaces, visitors' paths and sanitary areas. At the intersection of the two wings, corridors and transition zones, he placed a broad staircase between the entrance and the facilities and also the billiard room and the refectory, with two smaller stages at both sides, inspired by the historical example of the Castle of Blois, ${ }^{19}$ in order to let visitors and patients use them separately, avoiding visitors to enter into the hospital wing or infirmary rooms.

The main staircase serves six floors and it forms the only vertical elements in the building along with the identical fire escapes at the ends of the wing, highlighted by a continuous glass front over the entire height on one side, and by a series of balconies on the other.

Banisters and railings are made of a Pyrex glass structure, filled with thick frosted glass encased in metal profiles. The lighting was done with the ceiling integrated light source and opal glass spheres. ${ }^{20}$

18. Ibid, 73.

19. Paesmans, "Het Sanatorium te Overijse (Tombeek)," 30.

20. Ibid, 28-31. 
The Concierge and Doctor's House

The concierge and doctor's house are located along the access lane (see Figure 13): both properties represent a modest replica of the so-called white villas, characterized by a clearly defined cubic volume exploded with wide glass windows. Unlike the sanatorium, here walls are plain white plastered without tiles. The caretaker's house is located on the main access to the domain, visualized through a concrete canopy, wide as the entire width lane, and caught in the middle by two columns on each side.

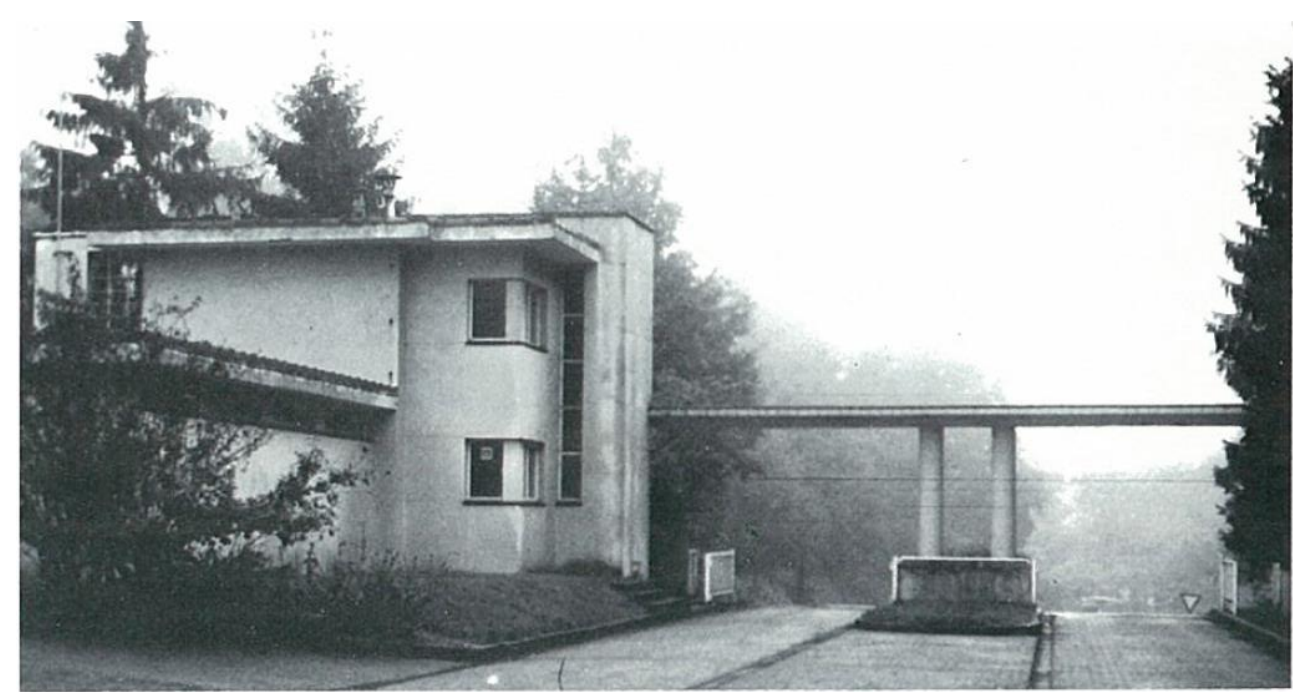

Figure 13. View of the Entrance Hall and the Caretaker's House Source: Paesmans, G. 1987.

This building is featured, like all the others, by a marked modernist style: a cubic volume broken by a vertical body containing the staircase, whose impact is emphasized by a narrow window that cuts over almost the entire height. The alternation of horizontal and vertical elements, that animates the composition, is combined with openings and windows on the garden, opposite to a few openings on the avenue side. The walls are covered of a Carrara granulated plaster. On the top a heavy roof overhangs of $80 \mathrm{~cm}$.

There are only two windows, one in the kitchen and one in the upper bedroom, which extend through the corner in two façades. On the rear on first floor there is a terrace that occupies the entire width of the volume with a parapet composed of three horizontal tubes. The use of fences and parapets made of round bent tubular sections - was, however, more symbolic than functional as they are in only one meter high.

The entrance is situated in a receding corner formed by the stairs and the toilet, linked directly to the canopy that spans from the wall over the entire avenue. Inside the concierge's house we find a regular and traditional partition: the kitchen occupies the main front towards the avenue and there is only a window; it is accessible from the living room by a glazed door under the wooden staircase. Next to it, a door leads to the basement. The living room is reached by a staircase from the entrance hall and it is L - shaped, occupying 
almost the entire width of the volume. Here the former mantelpiece made of Noir Belge marble has almost disappeared. ${ }^{21}$

On the first floor there are two bedrooms: the parents' bedroom had direct access to the bathroom, while the next room opens to the terrace.

The staircase is made of wood, the floor is linoleum covered, and both the hall and the kitchen are paved with square cream-colored tiles.

Next to the main volume, there is a low horizontal building that housed the garage, whose façade is featured by a narrow window that lengthens over the entire front. The garage is accessible from the kitchen by a door and it is divided by a transverse wall that separates two car parking areas.

The chief physician house is halfway between the avenue and is similar to the caretaker's. The front door is located in an inward angle which is formed by the head volume and a vertical volume in which the stairs are located. The kitchen looks just like that of the caretaker's house, on the avenue. Behind the house, across the full width, the rectangular living room has many windows and doors opening to the garden. As in the caretaker's, the fireplace is made of noble material, in this case a polished black marble from Flanders. Upstairs there are the bedrooms opening onto a terrace that occupies all the rear side and extends onto two small rotundas on both sides. The parapet here is also made of round tube profiles that follow the shape of the terrace. Although many common features, it is clearly appreciable that this house was better refined and intended for a more important person in confront of the caretaker's one.

\section{Present Status}

During the Second World War Lemaire was occupied by the Red Cross and its capacity grew up to 235 patients. In the postwar era it was slowly converted into a hospital for chronic disease and handicapped people, then into a neurological centre and finally it became a nursing home for elderly people.

In 1987 the Hospital was closed during the National Program for the Reorganization of Hospitals and since then it stayed empty and exposed to the passing of time. Degradation took over it rapidly, on one side because of the invasion of natural elements that reoccupied the built spaces, on the other because of the lack of maintenance works by the owners that exposed it to vandalistic attacks, arsonists and spoilers (see Figure 14).

On $13^{\text {th }}$ December 1993, six years after the closing, Lemaire Sanatorium was classified as a "monument of artistic, historical and architectural value" and as "an artistic valuable landscape". 22 Despite valuable and well prepared workforce and the willing to resume this complex, the situation worsened

21. Ibid, 31.

22. The status was declared by the Direction of Monuments and Landscapes of the Flemish Community on $13^{\text {th }}$ December 2003 as it is reported on: Working Part for Documentation and Conservation. New Internal Selection of Buildings, Sites and Neighbourhoods of the Modern Movement. Full Documentation Fiche. Docomomo International, 2003. DOI: http://www.ar chi.fr/UIA/ressourcesPDF/217_210.pdf 
inexorably: in 1994 the Herpain Company bought the building but vandalism and depredation kept on; in 2006 zinc roof of the service pavilion was stolen and therefore water flooded inside, worsening the already precarious conditions; external tiles fell down and due to the absence of an isolation layer between them and the concrete masonry the freezing during winter caused the falling of entire tracts of the walls.

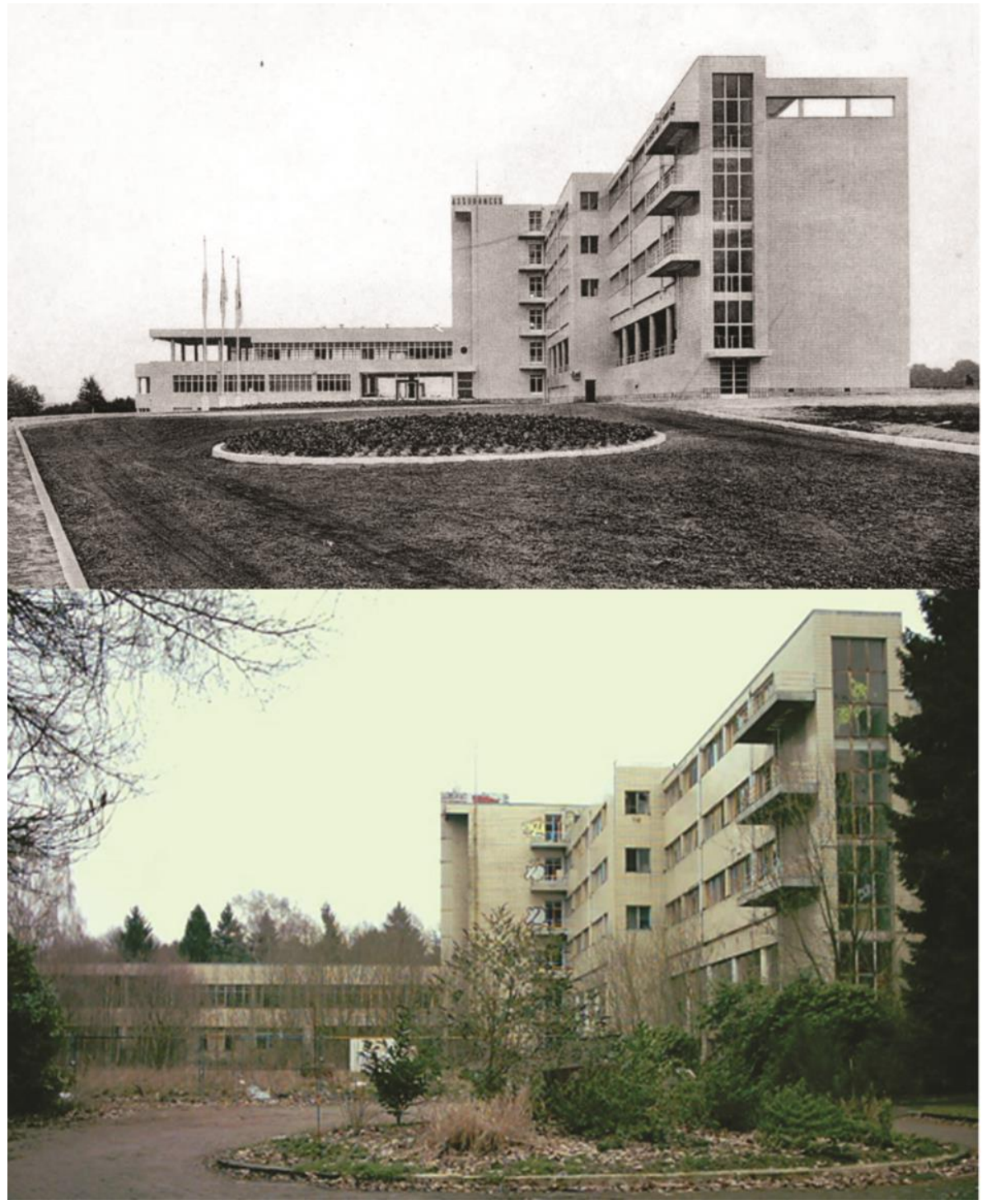

Figure 14. The Main Wing Today: Degradation Affects both External and Internal Spaces

Source: Graphic Elaboration by the Author.

In 2003 the campaigns Red Het Modernisme (Save the Modernism) and Red Het Sanatorium (Save the Sanatorium) promoted by Sint - Lucas Archive $^{23}$ raised the public interest in confront of the Lemaire Sanatorium,

23. Available at: http://www.sint-lukasarchief.be/. 
creating a website on the opportunities to save it as it had been done in Holland with Zonnestraal.

Unfortunately we have to wait until 2008 to come to a turn: the Flemish Minister of Cultural Heritage, Geert Bourgeois, assigned a $500.000 €$ fund to restore Lemaire, leaving it to the management of Tombeekheyde Kumpen NV Society, who assigned the architectural project to SVR Storme - Van Ranst architecture firm. $^{24}$

The program included the restoration and the extension of the site, the reuse of the building valorizing its monument potential and the realization of accommodations and supporting services, publicly accessible, and a memorial ward to preserve the original memories of the sanatorium. The project, started in August 2008 should be completed in November 2016 and involves about $16000 \mathrm{~m}^{2}$ for the restoration and about $6500 \mathrm{~m}^{2}$ for the extended parts, with a total cost of $21000000 €$ (SVR Architects, 2008: 1).

The main steps to get to a complete resume of the site have been the constant confrontation with the Flemish Agency for the Heritage in order to avoid the loss of the historical and modern values of the building; a study of the constructive features to start works, thanks to the disposal materials such as drawings and specifications found in the archives of the Amsab (Institute of Social History) and of the AAM (Archives d'Architecture Moderne). The Prévoyance Sociale provided photographic information, while a local resident, Mathieu Steensels, gave precious information about the building operations.

The survey also concerned the structure, the façades and the interiors: for the first the exams showed various kinds of damage and mapped them; the façades underwent photogrammetry to highlight joints and fissures; inside the original colours were brought to light thanks to stratigraphy tests.

\section{Conclusions}

Lemaire Sanatorium has been an abandoned masterpiece for about 22 years. Despite the initiatives to promote the safeguard and the valorization of its formal and historical values it suffered from degradation, vandalism and decadence. Unfortunately this is a common fate to many Modern buildings, although the restoration of modern architecture has been fortunately promoted and advanced by Institutions and Associations like Docomomo, Icomos, UNESCO and so on. Often only a few examples are saved and given back to their communities by private investors or buyers that aim to turn these complexes into private facilities. Nonetheless recovering programs should not forget that an ideological aspect of their mission is the sustainable resume of the identity values in confront of the history of places and communities, to which they formally belong: therefore, beside the involvement of private

24. "Former Sanatorium Lemaire," (SVR Architects, 2008), http://bit.ly/2cCQRNK. 
institutions and stakeholders, the participation and the accessibility of local actors are as important as the architectural restoration.

Zonnestraal Sanatorium, after a long period of oblivion, was rescued thanks to the attention of local administrations and by Docomomo International founders which approached the building resuming its constructive and formal potential. ${ }^{25}$ Since 1995 , a master plan on the original complex has not disturbed the narration of Duiker's original architecture, making it readable by the public and becoming an attraction more for its past than its present. ${ }^{26}$

Hoffmann's Purkersdorf Sanatorium in Wien was abandoned from 1975 to 1991 and, although the new owner started the restoration works in 1994, it was only in 2002 that a private company ${ }^{27}$ - bought it to set a nursing home. The restoration program aimed to resume its past features, therefore former alterations were canceled, furnishings were reproduced as the lost ones and the formal configuration of the entire building was finally discovered and opened to the public (see Figure 15).

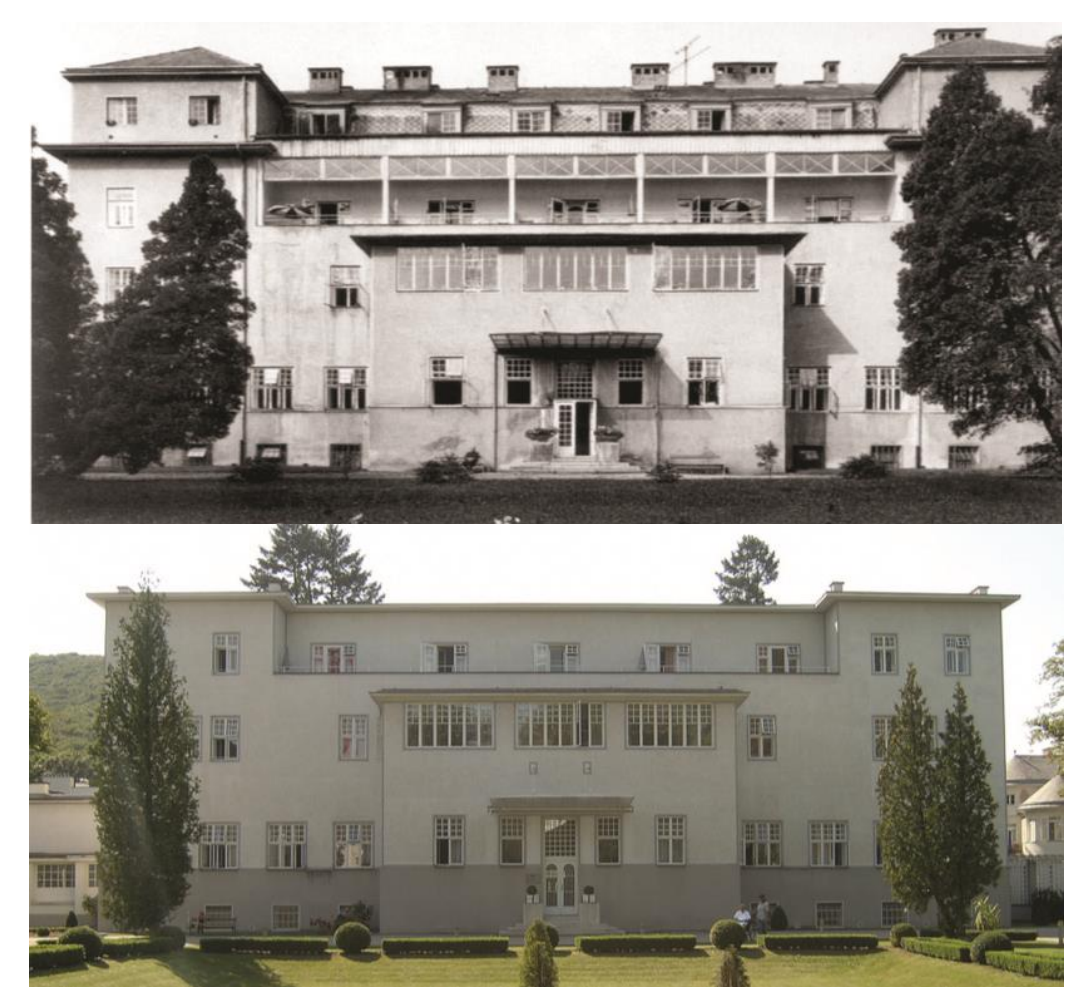

Figure 15. Hoffmann's Sanatorium in 1920s and After the Restoration Source: Graphic Elaboration by the Author.

25. "Award to Bierman Henket architecten and Wessel de Jonge architecten For the restoration of the Zonnestraal Sanatorium (1928-1931) Hilversum, The Netherlands. Designed by Johannes Duiker and Bernard Bijvoet," (World Monuments Found/Knoll Modernism Prize, 2010), http://bit.ly/2bPW2ZC.

26. Hubert Jan Henke and Hilde Heynen (ed.), Back from Utopia: The Challenge of the Modern Movement (Rotterdam: nai010 Publishers, 2002); Dario Cottone, Il restauro del moderno e il tema dell'uso [Restoration of the Modern and the topic of the use] (Rome: Aracne, 2011).

27. The BUWOG: Bauen und Wohnen GmbH, Building and Dwelling. [A. N.] 
Also for Lemaire Sanatorium, beyond the interest of National and International Authorities for the recognition and preservation of its values, ${ }^{28}$ there was a need for external partners - a private company in this case - to overtake the economical and political difficulties to set a reconversion program and on the other side the need of a tailored approach $^{29}$ to the restitution to local communities which this masterpiece belongs to: as in the other examples, it will house a nursing home but the importance of the restoration lies in the divulgation and in the opening to public audience. We thus hope that this building will be both restored in its architectural and structural features and also to be taken back to local communities, offering either public facilities and an example of sustainable recover.

\section{Bibliography}

Bray, Roberto. Alvar Aalto. Spazi e processo architettonico [Alvar Aalto. Spaces and architectural process.] Bari: Dedalo Libri, 1984.

Bryder, Linda. Below the magic mountain: a social history of tuberculosis in twentieth-century Britain. Oxford [Oxfordshire]: Clarendon Press, 1988.

Campbell, Margareth. Architecture of hope: hope for a cure. Tuberculosis, a design response. Graduation Thesis by Phil M. Edinburgh: Heriot-Watt University, 1999.

Casciato, Maristella and Wessel De Jonge. Johannes Duiker e il costruire funzionalista [Johannes Duiker and the functionalist building.] Milan: Mondadori, 1989.

Cottone, Dario. Il restauro del moderno e il tema dell'uso [Restoration of the Modern and the topic of the use.] Rome: Aracne, 2011.

D'Amato, Gabriella. Storia del Design [History of Design.] Milan: Bruno Mondadori, 2005.

Del Curto, Davide. Il Sanatorio Alpino. Architetture per la cura della tubercolosi dall'Europa alla Valtellina [The Alpine Sanatorium. Architectures for the cure of tuberculosis from Europe to Valtellina.] Rome: Aracne, 2010.

De Jonge, Wessel. "Zonnestraal: Restoration of a transitory architecture. Concept, planning and realization in the context of its authenticity." Paper Presented at the

28. This building might be considered as a symbol of the social security in Belgium before the second world war. The awareness of the thermal, hygienic, acoustical problems can be perceived in the way those problems have been solved and in the use of materials. This sanatorium is the first building in Belgium where the facades were covered in such a large scale with durable tiles.

The volume and design of the building, the openness, the execution of some details (ex. Some parapets of the stairs in glazed tubes) and the original (French) garden are jointly responsible for the high aesthetic value. The location on a hill of such as huge building in packet boat style makes this project in a certain way very surprising. Source: "Working Part for Documentation and Conservation. New Internal Selection of Buildings, Sites and Neighbourhoods of the Modern Movement. Full Documentation Fiche," (Docomomo International, 2003) DOI: http://www.archi.fr/UIA/ressourcesPDF/217_210.pdf.

29. Herdis A. Heinemann, "Why historic concrete buildings need holistic surveys," in Tailor Made Concrete Structures, ed. Walraven and Stoelhorst (London: Taylor \& Francis Group, 2008). 
$7^{\text {th }}$ International DOCOMOMO Technology Seminar Viipuri Library, Vyborg, Russia, September 18-19, 2003.

Fanelli, Giovanni. Architettura Moderna in Olanda [Modern Architecture in Holland.] Florence: Marchi e Bertolli, 1968.

Fleig, Karl (ed.). Alvar Aalto. Bologna: Zanichelli, 1978.

Ford, Edward. The Details of Modern Architecture. Cambridge: MIT Press, 1996.

"Former Sanatorium Lemaire." SVR Architects, 2008. http://bit.ly/2cCQRNK.

Frampton, Kenneth. Storia dell'Architettura Moderna [History of Modern Architecture.] Bologna: Zanichelli, 1986.

Greco, Alessandro and Enrico Quagliarini. L'involucro edilizio: una progettazione complessa [The architectural case: a complex design.] Florence: Alinea, 2007.

Heinemann, Herdis A. "Why historic concrete buildings need holistic surveys." In Tailor Made Concrete Structures. Edited by Walraven and Stoelhorst. London: Taylor \& Francis Group, 2008.

Henket, Hubert Jan and Hilde Heynen (ed.). Back from Utopia: The Challenge of the Modern Movement. Rotterdam: nai010 Publishers, 2002.

Hermant, André. "Constructions Hospitalières [Hospital Buildings.]" L'Architecture d'aujourd'hui 5. Boulogne-sur-Seine: L'Architecture d'aujourd'hui, 1938.

Keinänen, Timo et al. Alvar Aalto e gli oggetti [Alvar Aalto and the objects.] Milan: Electa, 2004.

McCarthy, O. R. "The key to the sanatoria." In Journal of the Royal Society of Medicine 94. London: Royal Society of Medicine, 2001.

Meurs, Paul and Marie-Thérèse van Thoor. Sanatorium Zonnestraal: History and Restoration of a Modern Monument. Rotterdam: nai010 Publishers, 2011.

Milelli, Gabriele. Zonnestraal. Il sanatorio di Hilversum [Zonnestraal. The Hilversum Sanatorium.] Bari: Dedalo Libri, 1978.

Novogordsky, L. "Le sanatorium Joseph Lemaire à Tombeek (Brabant) [The Joseph Lemaire Sanatorium in Tombeek (Brabant)]" In La Technique des Travaux 14. Bruxelles: La Technique des Travaux, 1938.

Paesmans, Greta. "Het Sanatorium te Overijse (Tombeek) [The Sanatorium in Overijse (Tombeek).]" In M\&L Monumenten en Landschappen 6. Brugge: Die Kure, 1987.

Prina, Vittorio. Jan Duiker: Sanatorio Zonnestraal a Hilversum [Jan Duiker: Zonnestraal Sanatorium in Hilversum.] Florence: Alinea, 2006.

Reed, Peter (ed.). Alvar Aalto. Milan: Electa, 1999.

Ryan, Frank. Tuberculosis: the greatest story never told. Bromsgrove: Swift Ed, 1992.

Sekler, Eduard Franz. Josef Hoffmann. Das Architektonische Werk [Josef Hoffmann. The Architectural Work.] Salzburg: Residenz Verlag, 1982.

Sekler, Eduard Franz. Josef Hoffmann 1870-1956. Milan: Electa, 1991.

Whittick, Arnold. Architettura europea del XX Secolo [European Architecture in the $20^{\text {th }}$ Century.] London: Crosby Lockwood \& Son, 1950.

"Working Part for Documentation and Conservation. New Internal Selection of Buildings, Sites and Neighbourhoods of the Modern Movement. Full Documentation Fiche." Docomomo International, 2003. DOI: http://bit.ly/2cvBFRx. [Accessed May, 2016]. 
